\title{
Folklore and Culture as Literacy Resources for National Emancipation
}

\author{
Olajide, Stephen Billy \\ English Education Unit, Department of Arts \& Social Sciences Education \\ University of Ilorin, Nigeria \\ Tel: 23-480-3964-2781/23-480-5667-8616Ｅ-mail: olajide.billy@yahoo.com
}

\begin{abstract}
Literacy counts a lot for development and progress. Efficient literacy induces and sustains good governance. Hence, all nations strive to attain balanced literacy. However any literacy programme that ignores the context of operation is not likely to be very successful. This paper canvasses that folklore and culture are essential ingredients for revitalizing literacy for national emancipation.
\end{abstract}

Keywords: Literacy, Folklore, Culture, Emancipation

\section{Introduction}

For decades, the world has made bold steps to produce more of literate citizens. Indeed, the Teheran conference of the 1960's (UNESCO, 1965) popularized literacy into a world agendum, and since then, nations after nations have made declarations (polices) on it. The world's commitment to literacy explains the role the ability to read, write and use numbers communicatively plays in the life of man. It improves family living, enhances rights awareness, and promotes international understanding. It also rekindles man's intellect, sensitizing him to his cultural milieu and enabling him to respect other peoples' cultures. Literacy oils the vehicle that globalization rides. However, in spite of the foregoing and other advantages of literacy, majority of the world have remained stark literates.

Literacy, like illiteracy, obtains in a continuum. Many of those who claim to be literate could become illiterate in certain contexts (Unoh, 1983). A highly educated individual, while good in his chosen field, may not be able to perform well elsewhere; somebody with a university degree in a critical area, like Medicine, may not be ICT compliant, he may not be able to fill banking transaction forms easily, thereby suffering from computer and/or document illiteracy. In other words, absolute literacy may not be easy to attain, especially in the developing world. The situation has continued to bother literacy workers, psychologists, applied linguists, sociologists, the media, and relevant other practitioners, leading to literacy and reading conferences where strategies for improvements are advanced and pursued.

Since the acquisition of literacy involves teaching, an aspect of literacy that requires urgent examination is its pedagogy which Jiboku (2002) called literacy education (p.188). How best literacy may be imparted deserves attention, and a key to the "how" appears to be linking literacy development to the learner-reader's culture, especially folklore, because a person's cultural exposure has influence on their intellectual disposition. According to Olajide (2006), folklore and culture enhance philosophical grounding and world view which a learner could bring to the class and utilize for effective language learning.

At the international level, the pedagogical relevance of culture was attested to in a study conducted by Cheung (2001). The researcher conducted the study using popular culture (which s/he defined to include 'television, special-effect movies, highly stimulating music, gossip magazines, comics, fashion, computer games and the Internet' pp. 56) to motivate a group of secondary school students in Hong Kong to learn English. S/he found that the students performed better with the use of popular culture. This implies that recognizing individual learners' backgrounds results in better educational outcomes. Based on the finding, Cheung recommended that language teaching should be made to benefit from popular culture.

\section{The Nature, Scope of Literacy}

Literacy workers and scholars are not agreed as to what constitutes literacy. While some view it as the number of years an individual spends in school, others consider it as the language skills possessed by the individual to make them function properly in school. Olajide (2007b) linked the various shades of literacy to the rungs of a ladder which are distinct, yet related. Contemporary reading scholarship tends to suggest that it may be more productive to treat literacy holistically, involving listening speaking reading and writing. The former two are oral skills, while the latter two are literacy skills (Lawal 1991; Olajide 1997). (Reading and writing are the higher order skills, while listening and speaking are the lower order skills.) The implication is that the lower order skills do not require formal teaching, but the higher order ones do. 
According to Uzodinma (1993), there are many types of literacy, including pre-literacy, post literacy, document literacy, graphic literacy and computer literacy. This possibly explains Unoh's (1983) observation about highly educated Nigerians that were still illiterate. It is not possible for all the citizens of most countries to be absolutely literate; you may be literate in one sense but illiterate in another! Functional literacy involves not only language skills, but also numeric skills by which the literate is able to act independently and in group ways. There is no end to literacy, because the literate is expected to continuously enhance their skills by reading and writing, speaking and listening. Thus, reading may be said to be central to literacy, the former being the ability to process (visual) symbols meaningfully (Olajide 1991). This implies that reading is not a matter for the print alone. Efficient readers also read the physical environments; they must read more than they write, otherwise, their writing would largely promote stale ideas.

The term "'emancipation" refers to freedom from crippling problems, such as poverty, hunger, lack of appropriate shelter and general underdevelopment. The freedom is attainable mainly through properly coordinated programmes, involving the use of available, and usually scarce human and material resources. Emancipation struggles are endemic in the developing countries, where most of the populations live below poverty line. The peoples' problems are compounded by gravely low levels of literacy.

\section{Literacy Situation in Nigeria}

Nigeria - this writer's home country - would seem to offer an interesting experience in literacy struggles. In the country, a programme tagged "Literacy for All by the Year 2000" was pursued with vigour. The programme drew international support. The federal government targeted the year 2000 for attaining full literacy and embarked on mass literacy campaign in 1982, having established a Centre for Adult Education in Kano, a city in the Northern part. Also, government launched the International Literacy Year and set up the National Commission for Mass Literacy, under Decree number 11 of the same year. As observed by Olajide (2002) 'the year is past and Nigeria remains largely illiterate' (p. 178). The people still face poverty, poor health delivery, drug trafficking, child labour, forced early marriage and gender disparity.

Government's efforts at attaining full literacy are however being supplemented with the programmes by private NGO'S and professional associations, such the Reading Association of Nigeria (RAN), Nigeria English Studies Association (NESA) and Nigeria Association of Language Educators (NALE) that organize conferences and workshops to interact on how best to tackle the nation's problem of illiteracy. They also conduct and sponsor research in the area of reading and reach out to their friends across the world soliciting aid for the promotion of literacy in the country.

The factors responsible for the worrisome literacy situation in Nigeria are many, including:

(1) Lack of correct census to support national planning;

(2) Less development-oriented educational policies that have made the country's dream of producing self-reliant learners (FRN, 2004a) most elusive;

(3) Undue emphasis on certain courses, like engineering, law, medicine and accountancy, to the neglect of others, like applied linguistics, literacy and reading, and language education;

(4) Diversion of aids and funds meant for the development of literacy;

(5) Inadequacy of media attention to literacy and related matters;

(6) Inordinate emphasis on prosperity, rather than the acquisition and application of knowledge, by spiritual leaders;

(7) The multilingual nature of the country; and

(8) The fluid nature of literacy, by which its boundaries are difficult to identify (you do not know at what point somebody should be regarded as being literate).

It is only through aggressive and persistent literacy drives that Nigeria could overcome these and other problems. As observed by Banjo (2010), a country would work if only all the people's energies are challenged, and over 80 per cent or even over 80 per cent of the people are functionally literate, 'which means that the people have their talents challenged in various ways' (pp. 28-29). The experiences of countries, like Tanzania, India and China that have attained impressive literacy levels through purposeful leadership could be instructive in this regard. Even though Nigeria and Tanzania had similar colonial experience and gained independence about the same time, the latter has been able to attain a far higher level of literacy. Balanced literacy, which involves what Ndukwe (2006) describes as '...READING, WRITING, KNOWLEDGE and SKILLS needed to operate in today's globally 
connected digital economy' (p. 1) is what Nigeria and other Third countries need urgently, and it is through education such could be availed.

\section{Views on Culture and folktales}

To a great extent, culture defines man: it helps to examine his predisposition to other men. How he relates with such other men in the struggle to liberate the environment is considerably determined by his cultural background. Culture differs from music, drama, or artifacts. Akonga (2003) and Dascal (2003) viewed culture as shared understanding. According to the former, culture covers such aspects of man's life as "norms, tales or laws that govern and control human behaviour; beliefs as in religion, superstition, witchcraft and sorcery, myths legends and ideology; and artifacts" (p.25).

There are usually rules and agreements as to the enforcement of culture. It does not matter if a culture is in the minority. Nevertheless, once culture is violated, conflict arises. Adeniyi (2003), a Nigerian pediatrics surgeon of repute and Akonga (2003), an outstanding Kenyan religious philosopher are agreed that cultural non-conformists hardly impact positively on their immediate environment. Malinowski (1996) specifically deposed that culture is a potent instrument for banishing poverty, ignorance, and desperation. The generative and definitive power of culture possibly led Dopamu (2003) and Oyewole (2003) to advocate that culture be vigorously studied across disciplines and races. One's culture provides the conceptual basis for one to accept or reject reality.

Thus, it may be said that every society's level of development and progress is a function of its cultural outlook. For example, the scientifically and technologically advanced countries have steady industrial culture which encourages them to explore their environments with great patriotism. The countries utilize their peculiarities in surging forward. Africans could also attain the desired industrial and technological breakthroughs by looking inward, making their culture the core of national planning (FRN, 2004b).

Folklore is an integral part of any culture. Olajide (2006) defined it as a "...collection of chants, mnemonics, incantation, songs, music, and stories derived from lullabies legends myths, proverbs, taboos and totems" (p.94). Folktales are derived from the daily experiences of ordinary people. The advent of western education in Africa (especially, south of the Sahara) has led to the formalization and systemization of African folktales (Ishola, 1995). Scholars like Adeyemi (1998) and Olajide believed that the medium of writing may have reduced the original flavour of folktales. In the olden days, elders gathered young ones, especially children, to tell them stories of dead people that had shown bravery, animal kingdom, birds, reptiles, and the gins. Those stories (folktales) have the following advantages.

(1) They sensitize children to the immediate environment.

(2) They help the children to develop self-confidence.

(3) They also sharpen the children's survival instinct.

(4) Folktales increase the children's patriotism.

(5) They enhance moral development.

Lawal, Ajayi and Raji (1997) exhaustively discussed the didactic and philosophical attributes of proverbs, recommending them for the language classroom. Also, Kachru (1991) and Olajide (2006) advocated the use of folktales in the teaching of English as a second language. There are different types of folktales, and many of them have been published as children's literature across Africa.

\section{How to Use Culture and Folktales in Literacy Work}

The forgoing discussion of culture and folktale would seem to show that literacy work has much to derive from them. Culture prepares the mind, while folktales serve as cultural reminders. On the other hand, literacy attempts to make the human mind so functional that it could address life's problems most rewardingly. The implication is that literacy workers and reading teachers need to be sufficiently familiar with the culture of their context of practice. They specifically require good knowledge of folktales for handling young clients and learners. They also need to be abreast of what people want education to do for them. Which means that literacy workers and reading teachers should have insight into the appropriate curriculum. Every nation states its educational aims in form of policy from where the curriculum is developed. Most African countries today want education for total liberation (from ignorance, wants and diseases). They spend heavily on education in the hope that it would lead to learners who could affect improved governance in the future, thereby bringing the nations to fame and glory.

Cultural experiences, especially from folktales (Olajide, 2007b) and popular culture items (Cheung, 2001) should be used in grooming young learners for future leadership. Perhaps the language classroom offers the most immediate opportunities for so doing, because right from the basic level, children learn language (Federal 
Republic of Nigeria, 2004a), and basic education is universal. Incidentally, learners carry much of culture and folktales into the class which the dynamic teacher could tap from. Also, Language teachers, in addition to their knowledge of listening speaking, reading and writing (the language skills) and familiarity with national educational policy, should be able to identify and relate with community resources. Other teachers, parents, the school, government, learner and relevant others are important sources of cultural information to the vibrant language teacher. A model personally developed by the present writer (Olajide, 2006) for incorporating folktales in the teaching of universal basic education [UBE] English (APPENDIX 1 in this paper) may be appropriate in this connection.

The foregoing model is an attempt to show interrelationships among language (literacy) skills, education policy, cultural context and language teaching-learning. As observed by Lawal (2006), the teacher is "the most crucial of instructional resources, being at once an initiator, a facilitator and sustainer off learning" (p.5). If folktales are appropriately employed by the teacher of literacy, the learners' language skills (including grammar) could be further enhanced. Olajide (2006) recommended pre-reading and post-reading activities, use of suitably graded comprehension questions, controlled writing and co-operative learning strategies when utilizing folktales in the ESL lesson.

There are constraints to the use culture and folklore as espoused in this paper. For example, most teachers may not be familiar with appropriate folktales. Also a lot of parents no longer pay attention to cultural matters, probably as a result of current religious status. Many of the folktales used in schools across Africa are likely to have been published by foreign authors. In addition, most Basic Education curricula may not provide adequate opportunities for the use of folktales (the curricula in Nigeria, according to Olajide (2006) do not!). Even where such folktales have been significantly published by indigenous writers and relevant books are recommended by government (as of Nigeria), poverty may prevent parents from buying them for their wards. And government may lack the funds to make the books available for free. Whatever may be the situation, the language teachers should try to use culture and folktale in their classes.

\section{Concluding Remarks}

Literacy is a powerful instrument for national development and integration. It involves reading, writing, and numeric and digital skills that are required to make one function effectively in the competitive global economy of today. Much as the entire world has devoted resources to, and co-operated on, the development of literacy, a worrisome proportion of mankind, especially in developing countries, has remained illiterate, leading to pitiable living conditions among the citizens. Nigeria is one example of such countries: she has a vision for full literacy as a means of eliminating graduate unemployment, social vices and general poverty, but poor leadership has made nonsense of such vision. Education steeped in the cultural heritage of the people, especially in folktales, could go a long way to ensure the attainment of national literacy objectives. Across the world, and in different forms, cultural elements abound that may be employed to enhance the teaching and learning of reading, writing, numeric and digital skills, which would result in leaders capable of fully liberating an impoverished people. Possessing such skills should constitute the citizens into a formidable and upwardly mobile workforce which emergent economies badly need. With perseverance on the part of the schools, teachers, parents, learners, governments and relevant others, most of the problems associated with the use of culture and folktales in the teaching-learning of literacy skills can be overcome.

\section{References}

Adeniyi, A. (2003). African culture, human health and scientific enquiry: Some reflections. In A. Dopamu (Ed.), African Culture, Modern Science and Religious Thought (pp.14 - 23). Ilorin: Nigeria: African Centre for Religions and Science, University of Ilorin, Ilorin, Nigeria.

Adeyemi. O. (1981). Nigerian folktales and their contributions to early child-care development andeducation. Centrepoint: A Journal of Intellectual, Scientific and Cultural Interest, 7(2), 109-123.

Akonga, J. (2003). Basic concepts of culture and their application to African social and cultural development. In A. Dopamu (Ed.), Africa Culture, Modern Science and Religious Thought (pp.14 -23). Ilorin: Nigeria: African Centre for Religions and Science, University of Ilorin,Ilorin, Nigeria.

Banjo, A. (2010, March 7). Sunday Tribune, pp. 28-30.

Cheung, Chi-Kim (2001). The use of popular culture as a stimulus to motivate secondary students' English learning in Hong Kong. ELT Journal, 55 (1), 55-61.

Dopamu, A. (2003). Preface. African Culture Modern Science and Religious Thought (pp. xii-xxiii). Ilorin: Nigeria: African Centre for Religions and Science, University of Ilorin, Ilorin, Nigeria. 
Dascal M. (2003). Understanding and understanding. Armsterdam/Philadephia: John Benjamin's Publishing company.

Federal Republic of Nigeria (2004a). National policy on education. Lagos: Government Press.

Federal Republic of Nigeria (2004b). National economic employment and development strategy (NEEDS). Abuja, Nigeria: Planning Commission.

Ishola A. (1995). The role literature in the intellectual development of the African child. In Owolabi K.(Ed.) Language in Nigeria: Essays in Honour of Ayo Bamgbose (pp.311-322). Ibadan: Group Publishers

Jiboku, O. (2002). Literacy, education and language education: two sides of a coin in national development in Nigeria. In R. A. Lawal, I. Abanihe, \& I. N. Ohia, (Eds.), Perspectives on Applied Linguistics in Language and Literature (pp.185-193). Ibadan: Stirling Horden.

Kachru, B. B. (1991). Non-active literature in English as a form of language teaching. In C. J.Brumfit \& R. A. Carter (Eds.),Literature and Language Teaching (pp. 140-149). Oxford: ELBS

Lawal, R.A. (1991). Influence of Selected Teacher variables on Cognitive Level of ReadingComprehension Questions. Paper Presented at the $5^{\text {th }}$ Biannual Conference of the Reading Association of Nigeria,3-6, September, 1991.

Lawal, R. B. (2006). A Schematized Framework for Building the English Studies Teacher's Professional Capacity. Paper Presented at the $1^{\text {st }}$ Staff Seminar, Development of Arts and Social Sciences Education, University of Ilorin, Nigeria on Wednesday, $26^{\text {th }}$ July,2006.

Lawal ,R.A., Ajayi, B. \& Raji, W. (1997). A pragmatic study of selectedpairs of Yoruba proverbs. Journal of Pragmatics, 27, 635-652.

Macharia, J. (2003). Cultural development through and communication. In A. Dopamu (Ed.), Africa Culture Modern Science and Religions Thought (pp. 92-106). Ilorin, Nigeria: African Centre or Religions and Science, University of Ilorin, Ilorin, Nigeria.

Malinowski, B. (1960). A scientific theory of culture and other essays. NY: Oxford University Press.

Ndukwe, E. C. A, (2006). Digital literacy: The compatible literacy model for the $21^{\text {st }}$ century Nigeria. Literacy and Reading in Nigeria, 11 (1), 1 - 3.

Olajide, S. B. (1991). Pattern of student performance in the of English programme of the University of Ilorin. Unpublished M. Ed. Thesis, University of Ilorin, Ilorin, Nigeria.

Olajide, S. B. (1997). Influence of university students' reading attitude and field of specialization on their comprehension performance in English. Literacy and Reading in Nigeria, 7,441-424.

Olajide, S. B. (2002). Revitalizing the Nigerian literacy Environment. In A.,Lawal, I, Abanihe, \& I. N. Ohia (Eds.), Perspectives on Applied Linguistic in Language and Literature (pp. 176-184). Ibadan: Stirling Horden.

Olajide, S. B. (2006). Folktales as effective means of teaching Universal Basic Education English in Nigeria. Journal of Professional Teachers, 1(2), 92-109.

Olajide, S. B. (2007a). Literacy and Reading in Nigeria. Unpublished mimeograph, university of IlorinNigeria.

Olajide, S. B. (2007b). The Place of Folklore and Culture in Revitalizing Literacy for National Liberation Paper Presented at the $5^{\text {th }}$ Pan-African Reading for All Conference, Held at the University of Ghana, Legon, Accra Ghana, $6^{\text {th }}-10^{\text {th }}$ August, 2007.

Oyedeji, L. (1997). Literacy for governance in Nigeria. Literacy and Reading in Nigeria, 7, 3-14.

UNESCO. (1965). Statistics of illiteracy. Paris: UNESCO.

Unoh, S. O. (1983). Keynote address: Reading improvement in Nigeria as a multilingual nation: Problems and prospects. Literacy and Reading in Nigeria, 1, 11-32.

Uzodinma, E.C.C. (1993). New approaches to adult literacy. Literacy and Reading in Nigeria, 6, 31-37. 


\section{Appendix I}

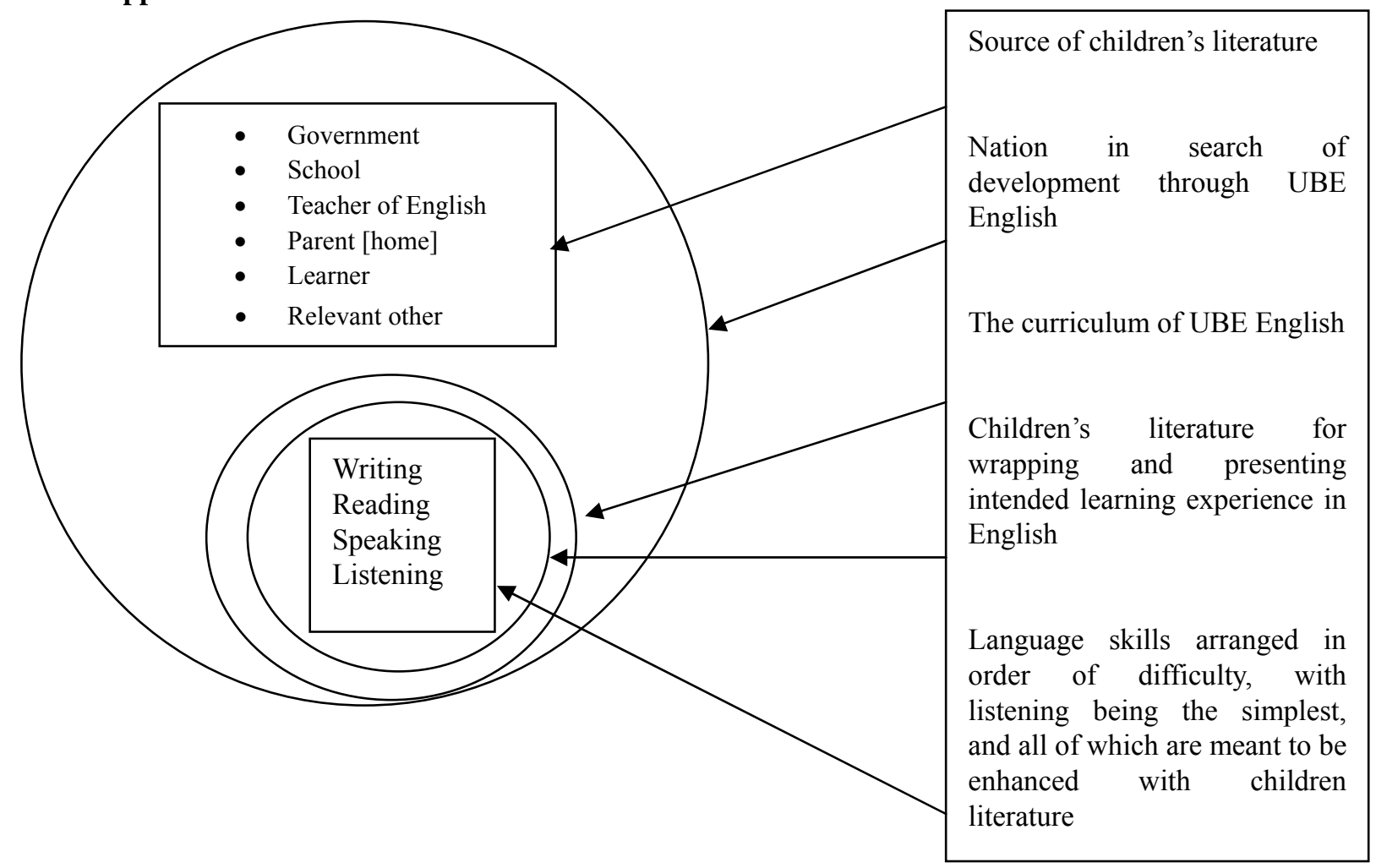

Figure 1. Olajide's (2006) model for incorporating folktales into the teaching and learning of UBE English

\section{Appendix II}

Affirmation to the Editor in Respect of Included Model

I hereby affirm that the Model that I have adopted in this paper (APPENDIX I, above) has been entirely my creation. It was first published in 2006 as acknowledged by me in the body of, and References to, the present paper. When it was published, I neither sold nor transferred my right to the Model to the journal house involved. Your Journal is thus at no legal risk publishing the model as part of another article by me.

Thank you.

(Signed)

Dr Stephen Billy Olajide.

Department of Arts and Social Sciences Education,

Faculty of Education,

University of Ilorin,

Nigeria. 